\title{
A Study on the Prediction of the Teaching Profession Attitudes by Communication Skills and Professional Motivation
}

\author{
Latife Kabakli Çimen \\ Correspondence: Latife Kabakli Çimen, Asist. Prof. Dr., İstanbul Sabahattin Zaim University, Education Faculty, \\ İstanbul, Turkey.
}

Received: August 30, 2016

doi:10.11114/jets.v4i11.1842
Accepted: September 2, 2016

Online Published: September 22, 2016

URL: http://dx.doi.org/10.11114/jets.v4i11.1842

\begin{abstract}
This study aims to investigate the prediction of the attitudes regarding teaching profession by the communication skills and professional motivation of pedagogical formation students. 261 pre-service teachers receiving pedagogical formation training Istanbul at a private university in the 2014-2015 academic year were included in the research as the study group. The personal information form developed by the researcher, motivation levels scale of pre-service teachers on teaching profession, teaching profession attitude scale and communication skills assessment scale were used in order to collect data. As a result of the study, it was found out that the attitudes of pedagogical formation students towards teaching profession do not vary significantly by gender, age, marital status, having a stable income, education level, regular works and training level, while the attitude towards the teaching profession varies by the bachelor's program graduated from, the reason for choosing teaching profession and the type of the university graduated from.

Communication skills and professional motivation levels we are significantly correlated with the attitudes of the student teachers taking pedagogical formation. The two variables in question explain 21 percent of the total variance in the attitude towards teaching profession.
\end{abstract}

Keywords: teaching profession, motivation, communication, attitudes

\section{Introduction}

Like in the past, teachers and raising teachers maintain their importance in terms of raising generations that will form the future of the countries. Forcing the social structure to change with the effect of many factors has made it compulsory to restructure the education system. This situation brought about new discussions and conflicts. A multi-dimensional process can be mentioned in the career choice and career orientation of an individual. Individuals can develop themselves, on the one hand, while healthily creating their personal development and social adaptation, on the other hand, via the professions they have chosen in accordance with their skills and interests (Üstün, et al., 2004).

Teachers are the most important elements in the successful implementation of the education system in line with the objectives. The teaching profession is the name of the profession which includes the activities regarding the process of initializing, directing, facilitating and realizing the learning of individuals in line with a particular purpose (Üstüner, 2006). The number and quality of teachers should be sufficient in order to be able to fulfil the objectives of the education system. While teachers are raised at Education Faculties, teaching certificate programs (pedagogical formation) and MA without thesis were initialized as a result of the high level of need for teachers. Thus, whether high-quality teachers are raised with these programs is discussed despite trying to fulfil the need for teachers (Yüksel, 2004). Students who graduate from the faculties other than the educational faculty or study at the third grade have started to be given pedagogical formation certificate programs as of the 2010-2011 academic year. Candidates who receive certificates by completing these programs get the right to become a teacher. In our day, teaching is regarded as a profession that requires special knowledge and skills. The preparation for teaching profession is ensured with general knowledge, field knowledge and teaching knowledge (Demirel, 1999). The quality of education is in direct proportion to the qualifications of the teachers to a great extent (Şişman, 2006).

Within the framework of these definitions, it is expected that the education given to pre-service teachers at educational faculties provide them with knowledge; as well as the skills to effectively use this knowledge. Having field knowledge obtained during professional training is not sufficient alone to practice the teaching profession successfully and professionally. In addition, teachers should first know what to teach and how to teach while teaching their students the 
ways to learn, be in peace with themselves and other people, and practice their profession willingly and gladly (Ocak, 2005). An individual is primarily expected to have a high level of communication skills and motivation, and positive attitudes towards one's profession in order to be able to practice one's profession willingly, gladly, efficiently and effectively.

\subsection{Attitude towards the Teaching Profession}

The term "attitude" is encountered when it is desired to examine human behaviours. The attitude was defined by Budak (2005) as quite a stable and judgmental tendency that leads an individual to thinking, feeling and acting positively or negatively towards a particular person, group, object, incident". The elements of the attitude are thoughts, emotions, and behaviours. Attitude is regarded as not only the tendency of a thought, feeling or behaviour but also the integration of the tendency of thoughts, feelings and behaviours. The attitude of a teacher towards his/her profession both represents his/her professional approach and determines how he/she will practice his/her profession (Şenel et al., 2004; Çetin, 2006).

Pre-service teachers should first know that teaching is a specialty profession and should gain professional awareness in order to develop a positive attitude towards their profession (Şimşek, 2005, Yılman, 1987). On the other hand, the attitudes, behaviours, interests and needs of teachers create their personality, which is effective on students (Küçükahmet, 1994).

According to Bonbour, a person who is in accord with his/her profession and with his/her personality traits will show a better attitude toward one's profession (Bonbour, quoted by: Külahoğlu, 2000). Şimşek (2005) stated that the qualification of a teacher is closely related to the attitudes of pre-service teachers towards teaching profession to a great extent. According to Kağıtçıbaşı (1985), explains the relation between attitudes and behaviours; it is a behavioural aspect of an attitude which helps predict the direction of an individual's attitude. Also, it is possible that behaviours affect attitudes. Attitudes are created at a later time by being affected from different sources. For this reason, the attitudes towards the teaching profession are important as they will affect the behaviours of the teachers. According to Sümbül (2003), teachers who have positive attitudes towards the profession will love their profession and try to practice it in the best way. Çeliköz \& Çetin (2004) state that when pre-service teachers develop positive attitudes towards their professions, they will fulfil their tasks fully, develop inquisitive and creative thought, motivate students more easily, transmit their verbal and non-verbal messages to the students in harmony, use time effectively and be open to innovations when they become teachers. While according to Semerci \& Semerci, (2004), positive attitudes towards the teaching profession include being interested in the profession, loving children and seeing the importance of education and teaching.

According to Semerci \& Semerci (2004), negative attitudes towards teaching profession are not loving children, not developing oneself, not being excited and willing; while according to Sümbül (2003), teachers with negative attitudes will reflect this negativity on their behaviours as well. The education system and especially children will be affected by this. While teachers are models for students, children gain values and attitudes by identifying themselves with the roles of their peers and adults, and especially their teachers, in addition to their inner motivation (Sümbül, 2003).

\subsection{Remove Red Part}

According to Semerci and Semerci (2004), positive attitudes increase success by facilitating learning and teaching, while negative attitudes decrease success. In terms of raising teachers, the attitudes of pre-service teachers towards their professions should be determined in order to raise highly qualified teachers and increase the success of the pre-service teacher education

As one of the main elements of the education system, teachers undertook the responsibility to raise students in a qualified way in line with the needs and necessities of the era. Teachers should be able to develop positive attitudes towards their profession before service and have field knowledge in order to be able to adequately fulfil this responsibility and increase the quality of the education system (Karadağ, 2012).

The attitudes of the teachers towards the profession have a key role in what kind of teachers they will be (Mc Ginnis et al., 1998; Quoted: Seferoğlu, 2004). According to Yilmaz (1996), teaching is a dynamic profession and teachers should not maintain their professional lives only with the knowledge they obtain in education institutions. The method dimension of the teaching profession is at least as important as its content dimension. Knowing about a subject very well is not sufficient to be able to teach it most of the time. Positive attitudes towards a profession can facilitate overcoming many problems.

Küçükahmet (1976) stated that attitudes towards students and school studies affect the learning and personal development of the students. Besides Varış (1988) also emphasised that teaching is a profession that requires positive attitudes and behaviours in addition to knowledge and skills, and that pre-service teachers gaining values and attitudes regarding the profession is at least as important as knowledge. 
Attitudes of teachers towards their profession are quite important in fulfilling the needs of the profession (Durmuşoğlu, Yanık and Akkoyunlu, 2009). For, the attitudes and perceptions towards a profession affect the professional competence perceptions and their success in the profession (Terzi \& Tezci, 2007). According to Bloom (1998), affective features of individuals affect their success. Thus, it can be said that the positive attitude is an element that may have an effect in direct proportion to the success of the students.

Baron and Byrne (1988) stated that the attitudes of individuals affect the decision they make on the subjects such as lifestyle and career selection. The attitudes towards a profession are mainly shaped by the education institution where that profession is obtained, and subsequently, the experiences in professional life. At this point, the attitudes of pre-service teachers towards the profession they will practice after university education are quite important. The attitudes of teachers, the actual purpose of the profession of whom is to ensure permanent and desired behaviour change, towards their profession will reflect on the behaviours of their students in addition to how much successfully and gladly they practice their profession. Teachers are role models for students with children acquiring values and attitudes by identifying themselves with the roles of their peers and adults, especially their teachers, in addition to their inner motivation (Sümbül, 2003). Furthermore, Peck, Fox and Morston (1977) revealed that the self-respect of the students of the teachers showing positive attitudes is higher (Quoted; Bishay, 1996). These studies show that attitudes significantly affect an individual's love, hate, and behaviours (Morgan, 1991).

It was found out that the attitude of the teachers, who prefer teaching as they like it, towards teaching profession is more positive (Gürbüz and Kışoğlu, 2007; Sağlam, 2008). According to Özder, Konedralı and Zeki (2010), the attitude scores of the pre-service teachers who preferred their profession "with the desire to become a teacher" were found to be higher than those of the pre-service teachers who preferred it as a result of "employment guarantee and working conditions" or "family request". Aydın and Sağlam (2012) concluded that those who prefer teaching in order to "develop themselves" show more positive attitudes towards the teaching profession when compared to those who prefer it as they "have to".

According to the studies carried out in Turkey on the reasons of pre-service teachers to prefer the teaching profession, it can be said that pre-service teachers consciously prefer the teaching profession (Övet, 2006; Gürbüz and Kışoğlu, 2007). According to Hoşgörür et al. (2002), the reason why pre-service teachers prefer the teaching profession is based on "the desire to become a teacher"; according to Argun (2003), it is based on loving children and the field; and according to Saban (2003), it is primarily based on dedication-based factors.

Çapri and Çelikkaleli (2008) and Demirtaş, Cömert and Özer (2011) examined the professional attitudes and competence beliefs of pre-service teachers; Çiğdem and Memiş (2011) examined the learning styles of pre-service classroom teachers and their attitudes towards the profession; Başbay, Ünver and Bümen (2009) examined the attitudes of secondary education field teaching non-thesis master's degree students towards teaching profession and Ulusoy (2012) examined the interpersonal relationship dimensions of the pre-service teachers and their attitudes towards teaching profession. According to Üstün, Erkan and Akman (2004), the attitudes of the students of the Pre-School Teaching Department, according to Kaya and Büyükkasap (2005), the attitudes of the students of Physics Teaching, and according to Akpınar, Yildız and Ergin (2006), the attitudes of the students of Science Teaching towards teaching profession are generally positive.

Many studies were carried out on the investigation of the attitudes of pre-service teachers studying at different departments of education faculties in Turkey towards teaching profession (Baykara- Pehlivan, 2008; Bedel, 2008; Çapri and Çelikkaleli, 2008; Oğuz and Topkaya, 2008; Temizkan, 2008; Bulut, 2009; Çetinkaya, 2009; Üstüner, Demirtaş and Cömert, 2009; Can, 2010; Coşkun, 2011; Tekerek and Polat, 2011; Açışlı and Kolomuç, 2012; Bektaş and Nalçac1, 2012; Karadağ, 2012; Kızıltaş, Halmatov and Sarıçam, 2012; Çağlar, 2013). In these studies, it was determined that pre-service teachers have a positive attitude towards teaching profession.

\subsection{Motivation towards Teaching Profession}

Many definitions have been made on the term of motivation. According to Koçel (1999), it is the process in which individuals act in accordance with their own desires and wishes in order to achieve a particular objective; Motivation includes various internal and external factors and functioning mechanisms that drive the organism towards a particular behaviour, determine the intensity and energy level of this behaviour, direct and give meaning to it and ensure its permanence (Akbaba, 2006). For Emir and Kanlı (2009), it means that an individual becomes ready with the effect of one's impulses and needs, acts in line with one's objective, and relaxes after achieving it. For Aydin (2010), it is various internal and external factors that drive the organism to a particular behaviour, determine the order and permanence of these behaviours and direct and give meaning to the behaviours; for Güney (2011), it is the process of affecting and encouraging which ensures mobilising an individual; and for Robbins and Judge (2012), it is the effort towards any aim.

According to Hanson (2003), hedonism underlies motivation. For this reason, people head towards the works they enjoy while they move away from the works for which they feel sadness or pain. This point-of-view that constitutes the basis 
of the idea that needs underlie motivation is content theories that seek the answer to the question "What motivates people". In subsequent studies, it was claimed that the question "What motivates people?" remains incapable of explaining motivation, and what is actually important is the question "How do people become motivated?" This point-of-view has led to the emergence of process theories in motivation. Process theories are motivation theories that try to explain how people are motivated. Process theories are concerned with how the process of motivation works and with which objectives people are motivated.

Motivation is impelling behaviour towards a particular direction. Motivation has 4 functions. These functions can be listed as follows [1 and 2]: initializing the behaviours (impelling them with a stimulant coming from the inside), determining the level of violence and energy of behaviours, guiding the behaviour (object-organism-situation, i.e., associating behaviours and particular targets), and ensuring the behaviour (realizing a particular target). According to Fenny and Wang (2010), motivation is the way of understanding the behaviours and dynamics that are desired, planned and attempted to be realized. Motivation is not only necessary for impelling, but also holding oneself and creativity. In realizing motivation, hoping, keeping one's mood up, showing patience and believing are also among the things that are necessary [3]. Different personalities lead to differentiations in motivation as well. Furthermore, everyone is motivated in a different way in achieving status and success. Individuals can determine their own advancement, and become individually motivated.

Güney (2011) states that motivated individuals practice their job gladly and this positively affects the efficiency of both themselves and the institution. Various studies have been carried out on motivation in the field of education (Büyükses, 2010; Karadağ, et al., 2010; Özan, et al., 2010 Mucherah \& Herendeen, 2013; Rodriguez-Keyes, et al., 2013; Yu, 2013). The dimensions of motivation and factors related to motivation, and especially attitudes were examined in these studies. As a result of the studies, it was found out that motivation and attitude are related (Azizoğlu and Çetin, 2009; Akandere, et al., 2010; Csizer, et al., 2010; Özan, et al., 2010; Djigunovic, 2012; İçöz, 2012; Emmett, 2013; Erdem \& Gözüküçük, 2013; Geri, 2013; Siskandar, 2013; Sougari \& Hovhannisyan, 2013; Uçgun, 2013).

The professional success of an individual and maintaining this success depend on the individual's motivation towards one's profession. A high level of motivation and maintaining this motivation are quite important especially in teaching profession. The efficiency of teachers will come up to the extent that they can motivate themselves, and their relations with the students, families, institution and social environment will turn into a product of knowledge and cultural acquisition (Büyükses, 2010). Teachers' level of motivation will not only have an effect on the teacher's own attitude towards learning but also on the motivation of the students. For example, the type and level of teacher motivation affect the internal motivation levels and autonomy of the students (Bieg and Mittag, 2009; Fischer \& Rustemeyer, 2007; Quoted by: Bieg et al., 2011). In case of lack of motivation in the academic sense, an individual will give up easily and exhibit behaviours such as impatience, indetermination and not enjoying one's work (Colengelo, 1997; Quoted by; Terzi et al., 2012).

Whether consciously or not, teachers affect the learning, success and motivation of the students. That teachers appreciate students is also very effective for the motivation and personality development of the students. The perceptions of the teachers about using learning strategies critically affect their work, student motivation, and success. Teachers using effective motivation methods may turn their students into active and successful students in their personal and academic lives. According to Czubaj (1996), that teachers love their profession and are constantly motivated about it both ensure that students understand what is taught by teachers well and also become motivated about learning.

According to Taş (2005), it is for sure that motivation ensures efficiency, efficiency ensures quality, quality ensures satisfaction, and satisfaction ensures work continuity. A conscious motivation is necessary to increase the efficiency of the teachers and ensure the continuity of this efficiency. For this, one must be aware of the factors that motivate and decrease the motivation of the teachers, and the opportunities, which will help them work happily, serenely and willingly in their education environment, should be provided taking these factors into consideration.

Motivation comes out as an effective tool in education that teachers need most recently. That teachers have a high level of working motivation is quite important in their being effective and efficient, work satisfaction and work performance. Furthermore, that teachers have a high level of working motivation will also affect the success of the students positively. At this point, it is necessary and important to examine the factors affecting the working motivation of the teachers. Upon examining the local literature about the working motivation of teachers, it is seen that the studies on this subject are limited in number (Demirci, 2011; Tanrıverdi, 2007; Y1lmaz, 2009).

Motivation of the teachers is extremely important both in terms of motivating the students in the classroom and further education reforms. Motivated teachers have a very important function in performing the reforms in education, implementing the changes that occur later on, ensuring success and satisfaction (Deci \& Ryan, 1985; Günbayı, 2001; Jesus \& Conboy, 2001; Azar \& Henden, 2003; Cenkseven-Önder \& Sar1, 2009; Yazıc1 2009; Roness, 2011). 
Motivation is accepted as a power that guides an individual towards particular objectives and ensures that he/she acts in line with these objectives. When this power is effectively used, it facilitates the access of an individual to his/her targets. Pedagogical formation students, who will become teachers in the future, should be motivated in their targets to fulfil the objectives of the education.

\subsection{Communication Skill}

Communication is defined as the process of producing, transferring and giving meaning to information (Dökmen, 1997), a psycho-social process that forms a relationship between two people (Cüceloğlu, 2000), transferring others emotions, thoughts and knowledge in any way that one can think of (Baltaş and Baltaş, 2002), and the process of sharing information, skills, emotions, thoughts, attitudes and demeanours or rendering meaning mutually (Bolat, 1990).

The communication skill consists of learnt behaviours that facilitate an individual's living with the society by establishing satisfactory relationships with others and transferring one's emotions and thoughts to others without masks and with I language by using empathy and respect effectively (Şahin, 1998). Effective communication skills may facilitate human relations and the relationships in any kind of profession areas. Especially the workers in the profession fields that require being together with people should control their communication skills more (Korkut, 2005).

That the parties can correctly transmit their emotions and thoughts in communication (Johnson, 1996) has an important place in the effectiveness of communication, and education is regarded as a communication activity on its own in this aspect. The realization of this activity in the most efficient way is mostly attributed to the quality of the communication between the teachers and students. The element which is among the most important qualities that the teacher must have in the education environment and closely concerns the success of the student is communication skills. Sufficient communication skills ensure the formation of democratic behaviours among people and the solution for social problems, and adaptation becomes easier. Among the skills that effective teachers must have in terms of their professional roles are being clear in communication, fully explaining what is expected, being able to communicate well with students and other staff and being sensitive in affective and social terms (Yüksel, 2001). Effective teachers may take their educator personality to the highest level by creating an effective impression in the process of teaching and establishing positive relations with the students by having the ability to perceive verbal and non-verbal messages and perceive the meaning under the messages.

Communication cannot be realized as long as the meaning of the message that is desired to be given is not shared by the parties exactly in the same way. In certain studies (Çulha and Dereli, 1987; Özer, 1995), it is indicated that communication problems in our country tend to increase. The subject that must be strongly emphasised is that all of the teachers and pre-service teachers are aware of the fact that they must communicate with their students and each other, no matter what their field is. Accordingly, considering that learning-teaching environments are generally environments of communication, the communication with the school and the environment apart from the students affect the professional behaviours of the teachers, it can be said that the communication skills of teachers will be effective in solving professional problems and becoming successful (Baykara Pehlivan, 2005).

According to Azian, Raof, Ismail and Hamzah (2013), oral communications of the teachers are among the most important elements of education and teaching. Accordingly, it can be said that the success of the teacher is associated with his/her communicating well with the students in the classroom, and the effect of the education depends on improving the communication processes (Alper, 2007). In the situations when communication is not healthy, people may feel lonely, outcast or professionally unsuccessful; and consequently, may lose their productivity and satisfaction (Çifçi and Taşkaya, 2010).

Literature studies on the communication skills in the education environment show that the effective communication skill of teachers is effective in increasing the academic success of their students (Baker, 2006; Buyse et al., 2009; Davies and Igbal, 1997; Hallinan, 2008; Montalvo, Mansfield and Miller, 2007; O'Connor and Mc Cartney, 2007), liking the school more, and the increase in in-class participation (Brich and Ladd, 1997; Buyse et al... 2009; Justice, Cottone, Mashburn and RimmKaufman, 2008). Güçlü (2001) concluded that it is the result of the communication and positive relationship between the teacher and student that the student likes the lesson and gains the habit of studying. A healthy communication between the teacher and the student is necessary for the required behaviours of the students as well as high academic success (Aspy and Roebuck,1977; Brophy and Evertson, 1976).

Studies carried out show that teachers with effective communication skills positively affect the adaptation of the students to the school (Pianta, Steinberg and Rollins, 1995), which creates positive effects on the emotional, social and cognitive development of the students as well (Vondra, Shaw, Swearingen, Cohen, and Owens, 1999; Tsigilis and Gregoriadis, 2008; Koepke and Harkins, 2008; Buyse, Verschueren, Verachtert and Van Damme, 2009; Rudasill, 2011). There are studies showing that effective communication methods used by the teacher in the classroom have positive effects on the perception of the classroom environment by the student, participation in the lesson and the 
communication with the teacher. The studies of Myers, Martin and Mottet, (2002) and Claus, Booth-Butterfield and Chory (2012) show that the effective communication methods used by the teacher in the classroom have positive effects on the perception of the classroom environment by the student, participation in the lesson and the communication with the teacher.

As the number of the studies on interpersonal communication processes and skills in teaching-learning environments in our country is limited (Akkuzu and Akkaya 2014; Argon and Zafer 2009; Başaran and Erdem 2009; Çetinkanat, 1997; Hazneci 2012; Karagöz and Kösterelioğlu 2008; Tarhan 2000), it is especially important to investigate the relationship between the communication skills and professional attitude of pre-service teachers receiving pedagogical formation education.

\subsection{Attitude, Motivation, and Communication Regarding Teaching Profession}

It is quite important to practice one's profession gladly and willingly in addition to being competent in the field of communication in order to be successful in the teaching profession. Therefore, it becomes necessary to determine with which processes and mechanisms teachers ensure academic success while they practice their profession (Caprara et al., 2006). There are many variables affecting the level and purposefulness of the teaching efforts of teachers. According to Rimm-Kaufman and Sawyer (2004), the attitudes and priorities of teachers are closely related to their behaviours and practices in their classes.

According to Can (1987), learning the professional attitudes of teachers later on like other attitudes show the importance of teacher's training. It is obligatory to determine the attitudes of pre-service teachers towards the profession and change them in a positive direction, if they are negative, in order to increase the success of the curriculum (Semerci and Semerci, 2004). The result of many studies carried out shows that students who prefer the teaching profession willingly and gladly have a more positive attitude than others (Üstün, Erkan and Akman, 2004; Aslan and Akyol, 2006; Bozdoğan, Aydın and Yıldırım, 2007; Doğan and Çoban, 2009; Üstüner, Demirtaş and Cömert, 2009)

Individuals with a high motivation level will show more effort in order to achieve their targets, show a more challenging attitude towards the difficulties they encounter, practice their profession willingly and be satisfied with their job. Motivation levels and communication skills of pre-service teachers will positively affect their attitude towards teaching profession as well. A teacher who has developed certain attitudes towards his/her profession may not be expected to practice their profession in a successful and professional manner. It is considered that the attitudes of teachers which develop later on as a result of the education they receive and experience they gain are related to their level of motivation and communication skills. It is obvious that the attitudes and motivation levels of pre-service teachers, who have not completed their professional training yet, before they start their professional life, are also important in terms of raising and employing qualified teachers.

Those who have received pedagogical formation training can be appointed as teachers after fulfilling the necessary criteria. Thus, what the candidates who have chosen teaching as a profession and wait for being appointed think about the teaching profession is a very important subject that should be investigated.

Furthermore, upon examining the studies on the attitudes of pre-service teachers on their profession, it was seen that there are many studies on determining the attitudes of pre-service teachers studying at education faculties and in service teachers however, no study that investigates to which extent the motivation levels and communication skills of the pre-service teachers receiving pedagogical formation training predict their attitude towards the teaching profession was encountered. In this sense, this study becomes even more important considering the contribution it will make regarding this gap in the relevant literature.

It is accepted that raising teachers both with a high level of motivation and communication skills who exhibit positive attitudes towards their profession will contribute to the development of the countries by raising generations that will be raised by them as qualified individuals. This study was carried out in order to determine the level of prediction of the motivation levels and communication skills of the education faculty pedagogical formation students of their attitudes towards teaching profession.

\section{Method}

\subsection{Research Model}

This study is based on relational screening model. Screening models are research approaches that aim to describe a situation in the past and that still exists. In this study, the incident, individual or object, which are the subject of the research, are attempted to be defined within their own conditions and as they are (Karasar, 2002). Relational screening studies are studies in which the relationship between two or more variables is examined without intervening the variables in any way (Büyüköztürk, Kılıç Çakman, Akgün, Karadeniz \& Demirel, 2012). 


\subsection{Study Group}

The study group consists of 261 pre-service teachers who receive pedagogical formation training at a private university in Istanbul in the academic year 2014-2015. 234 (89.6\%) of the participants are female, and $14(10.4 \%)$ are male.

\subsection{Data Collection Tool}

The "Personal Information Form" developed by the researcher, the scale of the "Preservice Teachers' Motivation Levels Regarding the Teaching Profession", teaching profession attitude scale and Communication Skills Assessment Scale were used in the study.

\subsubsection{Personal Information Form}

It Was Developed by the Researcher in Order to Obtain Information about the Gender, age, marital status of the participants, the bachelor's program they graduated from, the type of university, whether they have a job with a stable income, if yes, what it is, and why they have preferred teaching.

\subsubsection{The Pre-Service Teachers' Motivation Levels Regarding the Teaching Profession Scale}

The "Pre-Service Teachers' Motivation Levels Regarding the Teaching Profession Scale" created by Acat and Yenilmez (2004) in order to determine the motivation levels of pre-service teachers was employed. The scale consists of 23 items and 5 options of Likert-type. The Cronbach's Alpha value of the "Pre-Service Teachers' Motivation Levels Regarding the Teaching Profession Scale" created by Acat and Yenilmez (2004) was found as 0.92 (Acat and Yenilmez, 2004: 129). While the Cronbach's Alpha value in this study was found to be 0.83 .

\subsubsection{Teaching Profession Attitude Scale (TPAS)}

TPAS developed by Çetin (2006) was used in order to determine the attitudes of pre-service teachers towards the teaching profession. The five-item Likert-type scale includes 35 items in total with 15 negative and 20 positive items. The scale consists of 3 dimensions in total, in which 22 items are about "love", 5 items are about "harmony" and 8 items are about "values". The Alpha coefficient of the Love dimension of the scale was calculated as 0.95 , that of the value dimension was 0.81 , and finally that of the Harmony sub-dimension was calculated as 0,76 .

The lowest score of the Teaching Profession Attitude Scale was 35, and the highest score was 175. The score interval between 92 and 119 was considered as neutral attitude, the scores above it we are positive, and the scores below it we are considered as a negative attitude indicator. The scale consists of three dimensions being harmony, love, and value, and it gives both separate and total scores for all three sub-dimensions. The Cronbach's Alpha reliability coefficient was .95 for the whole scale, .76 for the harmony dimension, 0.95 for the love dimension and .81 for the value dimension. The validity of the scale was tested using the scale developed by Aşkar and Erden (1987), and the correlation coefficients obtained were found as $r=.85$ for the total, $r=.74$ for the harmony dimension, $r=.97$ for the love dimension, and $\mathrm{r}=.57$ for the value dimension.

\subsection{Communication Skills Assessment Scale}

It was developed by Karagöz and Kösterelioğlu (2008) in order to determine the communication skills of the teaching staff. The reliability coefficient of the scale was determined as the Cronbach's Alpha with 0,775 in the practice carried out by Karagöz and Kösterelioğlu (2008). The trial scale developed as 51 items was reduced to 25 items as a result of the factor analysis. The items with the factor load below 0,45 were removed from this scale. The expert opinion was sought in order to ensure the content validity of the scale. As a result of this change, the reliability of the survey was calculated by Durukan and Maden (2010) once again; and the Cronbach's Alpha internal consistency of the whole test was determined as 0,91 . The data obtained from the survey were analysed by sub-dimensions, and general item averages were given.

\subsection{Data Analysis}

In this study, the multiple regression analysis was used in order to determine whether communication skills and professional motivation predict the attitudes of the teaching profession. The One-Way Variance analysis was used in order to determine the difference between more than two independent variables, and the unrelated t-test was used for the significance of the difference between the averages of two variables. The error margin was determined as .05 for all results.

\section{Findings}

The extent to which the attitudes of pre-service teachers towards teaching profession are predicted by the communication skills subscales is examined as the first research question of this study. Respect, expression skill, value, obstacles, motivation and democratic attitude subscales together show significant relations with the attitudes of the teachers towards the profession $\left(\mathrm{R}=0.34, \mathrm{R}^{2}=0.12, \mathrm{p}<0.01\right)$. The six variables in question together account for only $12 \%$ of the variance in 
the attitude towards teaching profession.

According to the standardized regression coefficient ( $(B)$, the relative importance order of the predictive variables on the attitude towards the profession is obstacles, democratic attitude, motivation, value, respect and expression skill. Upon examining the t-test results on the significance of the regression coefficients, it is seen that only two variables (obstacles and democratic attitude) are significant predictors on the attitude towards the teaching profession. The results of the findings are shown in Table 1.

Table 1. Multiple Regression Analysis Results on the Prediction of Communication Skills Subscales towards Teaching Profession

\begin{tabular}{|c|c|c|c|c|c|c|c|}
\hline Variable & \multicolumn{3}{|c|}{ Standard } & $\mathrm{T}$ & $\mathrm{p}$ & $\begin{array}{l}\text { Binary } \\
\mathrm{r}\end{array}$ & $\begin{array}{l}\text { Partial } \\
\mathrm{r}\end{array}$ \\
\hline Constant & 77.91 & 15.556 & & 5.008 & .000 & & \\
\hline Respect & -.227 & .667 & -.024 & -.340 & .734 & .143 & -.021 \\
\hline Expression skill & .129 & .565 & .016 & .229 & .819 & .168 & .014 \\
\hline Value & -.375 & .698 & -.035 & -.538 & .591 & .088 & -.034 \\
\hline Obstacles & 3.124 & .877 & .274 & 3.563 & .000 & .311 & .218 \\
\hline Motivation & .939 & .749 & .088 & 1.254 & .211 & .210 & .078 \\
\hline Democratic & .403 & .212 & .113 & 1.901 & .048 & .140 & .118 \\
\hline $\mathrm{R}=0.34 \quad \mathrm{R}^{2}=0.12$ & & & & & & & \\
\hline $\mathrm{F}(6-254)=5.54$ & & & & & & & \\
\hline
\end{tabular}

The extent to which the communication skills and professional motivation scales predict the love subscale in the attitude towards teaching profession was examined in the second research question. Communication Skills and Professional Motivation Scales together show significant relations with the scores of the attitude Love Subscale $\left(R=0.44, R^{2}=0.20\right.$, $\mathrm{p}<0.01)$. The two variables in question together explain only 20 percent of the variance in the attitude towards one's profession love subscale.

According to the standardized regression coefficient (ß), the relative order of importance of predictor variables on the attitude towards profession love subscale is professional motivation and communication skills. Upon examining the $t$-test results on the significance of the regression coefficients, it is seen that both of the variables are significant predictors on the attitude towards teaching profession love subscale. The findings are shown in table 2.

Table 2. Multiple Regression Analysis Results of Communication Skills and Professional Motivation Scales on the Attitude towards Teaching Profession Love Subscale

\begin{tabular}{|c|c|c|c|c|c|c|c|}
\hline Variable & B & $\begin{array}{l}\text { Standard } \\
\text { Error }\end{array}$ & B & $\mathrm{T}$ & $\mathrm{p}$ & $\begin{array}{l}\text { Binary } \\
\mathrm{r}\end{array}$ & $\begin{array}{l}\text { Partial } \\
\mathrm{r}\end{array}$ \\
\hline Constant & 1.407 & 11.679 & & 4.120 & .000 & & \\
\hline Communication & .245 & .105 & .142 & 2.342 & .020 & .284 & .131 \\
\hline $\begin{array}{l}\text { Motivation } \\
R=0.44 R^{2}=0.20\end{array}$ & .640 & .104 & .369 & 6.094 & .000 & .424 & .340 \\
\hline $\mathrm{F}(2-258)=31.54$ & $\mathrm{P}=.000$ & & & & & & \\
\hline
\end{tabular}

The extent to which communication skills and professional motivation scales predict the harmony subscale in the attitude towards teaching profession was examined in the third research question of this study. Communication Skills and Professional Motivation Scales together show significant relations with the scores of the attitudes harmony subscale of the teachers towards the profession $\left(\mathrm{R}=0.44, \mathrm{R}^{2}=0.20, \mathrm{p}<0.01\right)$. The two variables in question together account for only $20 \%$ of the variance in the attitude towards the teaching profession harmony subscale.

According to the standardized regression coefficient ( $($ ), the relative order of importance of the attitude of the predictive variables towards the profession harmony subscale is professional motivation and communication skills. Upon examining the t-test result on the significance of the regression coefficients, it is seen that both of the variables are significant predictors on the attitude towards teaching profession harmony subscale (Table 3)

Table 3. Multiple Regression Analysis Results on the Attitude towards Teaching Profession Harmony Subscale of Communication Skills and Professional Motivation Scales

\begin{tabular}{|c|c|c|c|c|c|c|c|}
\hline Variable & B & $\begin{array}{l}\text { Standar } \\
\text { Error }\end{array}$ & $\beta$ & $\mathrm{T}$ & $\mathrm{p}$ & Binary & Partial \\
\hline Constant & 2.945 & 2.999 & & 4.986 & .000 & & \\
\hline Communication & .081 & .027 & .181 & 3.003 & .003 & .316 & .184 \\
\hline $\begin{array}{l}\text { Motivation } \\
R=0.44 R^{2}=0.20\end{array}$ & .156 & .027 & .349 & 5.787 & .000 & .419 & .339 \\
\hline $\mathrm{F}(2-258)=32.88$ & $\mathrm{P}=.000$ & & & & & & \\
\hline
\end{tabular}

The extent to which the communication skills and professional motivation scales predict the value subscale in the attitude towards teaching profession was examined in the fourth research question of this study. Communication Skills 
and Professional Motivation Scales together show significant relations with the scores of the attitude of the teachers towards the teaching profession value subscale scores $\left(\mathrm{R}=0.27, \mathrm{R}^{2}=0.07, \mathrm{p}<0.01\right)$. The two variables in question together account for only $7 \%$ of the variance in the attitude towards teaching profession value Subscale.

According to the standardized regression coefficient (ß), the respective importance order of the predictor variables on the attitude towards the profession harmony subscale is professional motivation and communication scales. Upon examining the t-test results on the significance of regression coefficients, it is seen that professional motivation is a significant predictor only on the attitude towards teaching profession value subscale (Table 4).

Table 4. Multiple Regression Analysis Results on the Attitude towards Teaching Profession Value Subscale of Communication Skills and Professional Motivation Scales

\begin{tabular}{|c|c|c|c|c|c|c|c|}
\hline Variable & B & $\begin{array}{l}\text { Standa } \\
\text { Error }\end{array}$ & $\beta$ & $\mathrm{T}$ & $\mathrm{p}$ & $\begin{array}{l}\text { Binary } \\
\mathrm{r}\end{array}$ & $\begin{array}{l}\text { Partial } \\
\mathrm{r}\end{array}$ \\
\hline Constant & 11.908 & 5.337 & & 4.231 & .000 & & \\
\hline Communication & .071 & .048 & .096 & 1.479 & .140 & .182 & .089 \\
\hline $\begin{array}{l}\text { Motivation } \\
R=0.27 R^{2}=0.07 \\
F(2-258)=10.47\end{array}$ & .164 & .048 & .222 & 3.421 & .001 & .259 & .205 \\
\hline
\end{tabular}

The extent to which the communication skills and professional motivation scales predict the value total score of the attitude towards teaching profession scale was examined in the fifth research question of this study. Communication Skills and Professional Motivation Scales together show significant relations with the attitudes of the teachers towards the profession $\left(R=0.46, R^{2}=0.21, p<0.01\right)$. The two variables in question together explain only $21 \%$ of the variance in the attitude towards teaching profession.

According to the standardized regression coefficient (ß), the respective importance level of the predictor variables on the attitude towards the profession is professional motivation and communication skills. Upon examining the results of the $\mathrm{t}$-test on the significance of the regression coefficients, it is seen that both of the variables are significant predictors on the attitude towards teaching profession (Table 5).

Table 5. Multiple Regression Analysis Results on the Predicting the Attitudes towards Teaching Profession of Communication Skills and Professional Motivation Skills

\begin{tabular}{llllllll}
\hline Variable & $\mathrm{B}$ & Standard Error & $\beta$ & $\mathrm{T}$ & $\mathrm{p}$ & Binary $\mathrm{r}$ & Partial $\mathrm{r}$ \\
\hline Constant & 15.461 & 16.866 & & 6.917 & .360 & & \\
Communication & .308 & .151 & .122 & 2.041 & .042 & .276 & .126 \\
Motivation & 1.005 & .152 & .397 & 6.626 & .000 & .445 & .381 \\
$\mathrm{R}=0.46 \mathrm{R}^{2}=0.21$ & & & & & & & \\
$\mathrm{~F}(2-258)=34.41$ & $\mathrm{P}=.000$ & & & & & & \\
\hline
\end{tabular}

Whether the attitudes of the pre-service teachers on teaching profession differ by gender, type of university, income level, education level, age, marital status, bachelor's program, the reason for preferring the profession, the works they perform and the level of education they would like to work at was also examined in this study. The scores obtained from the Attitude Scale on the Profession of pre-service teachers according to the results of the t-test and ANOVA tests do not vary significantly by gender [t(259)=1.296, $\mathrm{p}>0.05]$, the status of having a stable income $[\mathrm{t}(258)=.388, \mathrm{p}>0.05]$, level of education $[\mathrm{t}(259)=1.117, \mathrm{p}>0.05]$, age $[\mathrm{f}(4-256)=1.62, \mathrm{p}>.01]$, marital status $[\mathrm{f}(2-258)=.726, \mathrm{p}>.01]$, the works they regularly carry out $[\mathrm{f}(4-233)=1.26, \quad \mathrm{p}>.01]$ and the education grade they would like to work at $[\mathrm{f}(2-258)=0.390$, p>.01] (Table 6 and Table 7).

Table 6. T-Test Results of the Attitude Scores towards Teaching Profession by Gender, Type of University, Income, and Level of Education

\begin{tabular}{lllllll}
\hline Variables & & $\mathbf{N}$ & $\overline{\mathbf{X}} \pm \mathbf{S}$ & sd & $\mathbf{t}$ & $\mathbf{p}$ \\
\hline Gender & Female & 234 & $143.36 \pm 22.94$ & 259 & 1.296 & .196 \\
& Male & 27 & $137.30 \pm 23.15$ & & & $.015^{*}$ \\
Type of University & Private & 64 & $136.67 \pm 26.88$ & 259 & 2.44 & .698 \\
Graduated from & State & 197 & $144.70 \pm 21.35$ & & .388 & .265 \\
Do you have & Yes & 150 & $143.09 \pm 22.29$ & 258 & 1.117 & .265 \\
stable income? & No & 110 & $141.96 \pm 24.01$ & & \\
Level of education & Graduate & 186 & $141.72 \pm 23.56$ & 259 & & \\
& Student & 75 & $145.24 \pm 21.62$ & & & \\
\hline
\end{tabular}

The scores obtained by the pre-service teachers from the Attitude towards the Profession differ significantly by the type of university graduated from $[\mathrm{t}(259)=2.445, \mathrm{p}<0.05]$. The scores of the graduates from the state university towards teaching profession $(\overline{\mathrm{x}}=144,70)$ are higher when compared to the graduates from a private university $(\overline{\mathrm{x}}=136,67)$. 
Table 7. ANOVA Results of the Attitude Scores towards Teaching Profession by Age, Marital Status, Bachelor's Program, the Reason for Preferring the Profession, the Works Carried Out and the Level of Education They Would Like to Work At

\begin{tabular}{|c|c|c|c|c|c|c|c|c|c|}
\hline \multicolumn{2}{|c|}{ Variables } & \multirow{2}{*}{$\begin{array}{l}\mathbf{N} \\
95\end{array}$} & \multirow{2}{*}{$\begin{array}{l}\overline{\mathbf{X}} \pm \mathbf{S} \\
138.76 \pm 23.39\end{array}$} & \multirow{2}{*}{$\begin{array}{l}\begin{array}{l}\text { Source of the } \\
\text { Variance }\end{array} \\
\text { Inter-groups }\end{array}$} & \multirow{2}{*}{$\begin{array}{ll}\begin{array}{l}\text { Sum of } \\
\text { squares }\end{array} \\
3403.86\end{array}$} & \multirow{2}{*}{$\begin{array}{l}\text { sd } \\
4\end{array}$} & \multirow{2}{*}{$\begin{array}{l}\text { Avg. } \\
\text { Squares } \\
850.96\end{array}$} & \multirow[t]{2}{*}{ f } & \multirow[t]{2}{*}{$\mathbf{P}$} \\
\hline & $20-25$ & & & & & & & & \\
\hline \multirow[t]{4}{*}{ Age } & $26-30$ & 78 & $145.33 \pm 21.23$ & & & & & & \\
\hline & $31-35$ & 55 & $143.45 \pm 23.08$ & Intra-groups & 134589.36 & 256 & 525.74 & 1.62 & .170 \\
\hline & $36-40$ & 25 & $144.04 \pm 27.69$ & & & & & & \\
\hline & $41-50$ & 8 & $155.50 \pm 15.24$ & Total & 137993.22 & & & & \\
\hline \multirow[t]{3}{*}{ Marital Status } & Married & 109 & $144.12 \pm 24.14$ & Inter-groups & 772.19 & 2 & 386.09 & & \\
\hline & Single & 148 & $141.47 \pm 22.29$ & Intra-groups & 137221.03 & 258 & 531.86 & .726 & .485 \\
\hline & Divorced & 4 & $151.73 \pm 23.03$ & Total & 137993.22 & & & & \\
\hline \multirow{5}{*}{$\begin{array}{l}\text { Bachelor's } \\
\text { program } \\
\text { graduated from }\end{array}$} & Religious science & 35 & $148.40 \pm 16.74$ & Inter-groups & 10471.11 & 5 & 2094.22 & & \\
\hline & Social sciences & 111 & $139.02 \pm 25.14$ & & & & & & \\
\hline & Health & 72 & $143.64 \pm 19.08$ & Intra-groups & 127522.11 & 255 & 500.08 & 4.18 & $.001^{*}$ \\
\hline & Engineering & 16 & $141.88 \pm 19.59$ & & & & & & \\
\hline & $\begin{array}{l}\text { Business } \\
\text { management/ } \\
\text { economy }\end{array}$ & 26 & $151.85 \pm 25.94$ & Total & 137993.22 & & & & \\
\hline \multirow{4}{*}{$\begin{array}{l}\text { Reason for } \\
\text { preferring the } \\
\text { teaching profession }\end{array}$} & Being a teacher & 149 & $143.03 \pm 24.15$ & Inter-groups & 6981.05 & 3 & 2327.02 & & \\
\hline & $\begin{array}{l}\text { Employment } \\
\text { guarantee }\end{array}$ & 52 & $136.21 \pm 21.43$ & Intra-groups & 131012.17 & 257 & 509.78 & 4.57 & $.004^{*}$ \\
\hline & Wish of the family & 6 & $125.33 \pm 29.59$ & & & & & & \\
\hline & Sacr & 54 & $150.11 \pm 17.82$ & Tota & 137993.22 & & & & \\
\hline \multirow{4}{*}{$\begin{array}{l}\text { Works performed } \\
\text { by those who have } \\
\text { stable jobs }\end{array}$} & Public & 106 & $141.72 \pm 19.03$ & Inter-groups & 2683.82 & 4 & 670.95 & & \\
\hline & Private education & 44 & $145.52 \pm 22.69$ & & & & & & \\
\hline & Self-employment & 21 & $133.48 \pm 36.78$ & Intra-groups & 124431.66 & 233 & 534.04 & 1.26 & .288 \\
\hline & Unemployed & 62 & $144.03 \pm 24.03$ & & & & & & \\
\hline \multirow{4}{*}{$\begin{array}{l}\text { Level of education } \\
\text { for teaching }\end{array}$} & Other & 5 & $151.00 \pm 22.05$ & Total & 127115.48 & & & & \\
\hline & Primary school & 32 & $145.13 \pm 15.92$ & Inter-groups & 416.40 & 2 & 208.20 & & \\
\hline & Secondary school & 34 & $140.12 \pm 24.44$ & Intra-groups & 137576.82 & 258 & 533.24 & .390 & .677 \\
\hline & High school & 195 & $142.73 \pm 23.03$ & Total & 137993.22 & & & & \\
\hline
\end{tabular}

However, the "scores of the attitude towards teaching scale" of pre-service teachers show significant differences by the bachelor's program they graduated from $[\mathrm{f}(5-255)=4.18, \mathrm{p}<.01]$. Accordingly, the scores $(\overline{\mathrm{x}}=151.85)$ of the graduates of business management/economy on the attitude towards teaching profession are higher than the graduates of religious sciences $(\bar{x}=148.40)$, health $(\bar{x}=143.64)$, engineering $(\bar{x}=141.88)$ and social sciences departments $(\bar{x}=139.02)$. The Scheffe's test was used in order to determine whether there is a significant difference between the groups, and significant differences were observed only between those who have graduated from the departments of business management/economy, religious sciences and social sciences.

The "scores of the attitude towards teaching scale" of pre-service teachers show significant differences by their reason for preferring the teaching profession [ $\mathrm{f}(3-257)=4.57, \mathrm{p}<.01]$. Accordingly, the scores $(\overline{\mathrm{x}}=150.11)$ of the attitude towards teaching profession scale of those who consider teaching as a sacred profession are higher than of those who choose this profession as a result of the wish of being a teacher $(\overline{\mathrm{x}}=143.03)$, employment guarantee $(\overline{\mathrm{x}}=136.21)$ and wish of the family ( $\bar{x}=125.33)$. Scheffe's test was used in order to determine whether there is a significant difference between the groups, and it was observed that the scale scores of only those who consider teaching as a sacred profession are significantly higher than of those who consider teaching as an employment guarantee.

\section{Discussion}

The relationship between the communication skills and motivations and their professional attitudes of the pre-service teachers receiving pedagogical formation training was investigated in this study. The findings of the study show that the communication skills and motivation levels of pedagogical formation students predict their professional attitude levels.

According to the research findings, the communication skills (respect, expression skill, value, obstacles, motivation and democratic attitude) of pedagogical formation students show significant relations with the teachers' attitudes towards the profession. The six variables in question explain only $12 \%$ of the variance in the attitude towards teaching profession. The relative importance order of the predicator variables towards the profession is obstacles, democratic attitude, motivation, value, respect and expression skill level. Upon investigating the t-test results on the significance of the regression coefficients, it is seen that only the levels of two variables (obstacles and democratic attitude) are significant predictors on the attitude towards teaching profession.

That the level of obstacles is a significant predictor on the attitude towards teaching profession results from the positive 
perception of the communication skills of pedagogical formation students. According to the findings of the study, it can be said that pre-service teachers want to consider the thoughts of oneself or others not as the only truth, to take the opinions of the students into consideration, show mutual respect and love, not to give commands, use body language effectively, guide rather than direct, and exhibit the attitudes and behaviours that are approved by the students.

Similarly, that the level of the democratic attitude is a significant predictor on the attitude towards teaching profession can be accepted as the indicator that pedagogical formation students have democratic attitudes such as understanding the emotions and thoughts of the students at the moment of communication, respecting others' rights and acting in accordance with the equality and justice principle.

The study findings display some similarities and differences with those of the previous ones. For example, Tümkaya (2011) also found that there is a significant positive relationship between the communication skills of the students and their attitudes towards teaching. Accordingly, as the communication skills of the students increase, their positive attitudes towards the profession also increase. This result is in parallel with our findings. Besides communication is an important skill for the teaching profession. It is possible to say that pre-service teachers with sufficient communication skills are more self-confident, and this affects their motivation and attitudes towards the profession positively.

According to the research findings, the communication skills (respect, expression skill, value, obstacles, motivation and democratic attitude) of pedagogical formation students show significant relations with the teachers' attitudes towards the profession. The six variables in question explain only $12 \%$ of the variance in the attitude towards teaching profession. The relative importance order of the predicator variables towards the profession is obstacles, democratic attitude, motivation, value, respect and expression skill level. Upon investigating the t-test results on the significance of the regression coefficients, it is seen that only the levels of two variables (obstacles and democratic attitude) are significant predictors on the attitude towards teaching profession.

That the level of obstacles is a significant predictor on the attitude towards teaching profession results from the positive perception of the communication skills of pedagogical formation students. According to the findings of the study, it can be said that pre-service teachers want to consider the thoughts of oneself or others not as the only truth, to take the opinions of the students into consideration, show mutual respect and love, not to give commands, use body language effectively, guide rather than direct, and exhibit the attitudes and behaviours that are approved by the students.

Similarly, that the level of the democratic attitude is a significant predictor on the attitude towards teaching profession can be accepted as the indicator that pedagogical formation students have democratic attitudes such as understanding the emotions and thoughts of the students at the moment of communication, respecting others' rights and acting in accordance with the equality and justice principle.

According to the results obtained from this study, the communication skills and professional motivation levels of pedagogical formation students show significant relations with the scores of the attitude of the teachers towards teaching profession love subscale. The two variables in question together account for only $20 \%$ of the variance in the attitude towards teaching profession love subscale.

According to the standardized regression coefficient ( $($ ), the relative importance level of the predictor variables on the attitude towards the profession love subscale is professional motivation and communication skills. Upon examining the t-test results on the significance of regression coefficients, it is seen that both variables are significant predictors on the attitude towards teaching profession love subscale.

According to the findings of the study, the communication skills and professional motivation levels of pedagogical formation students show significant relations with the scores of the attitude towards teaching profession harmony subscale. The two variables in question together account for only $20 \%$ of the variance in the attitude towards teaching profession harmony subscale.

According to the standardized regression coefficient (B), the relative order of importance of the predictor variables on the attitude towards teaching profession harmony subscale is professional motivation and communication skills. Upon examining the results of the t-test on the significance of the regression coefficients, it is seen that the two variables are significant predictors on the attitude towards teaching profession harmony subscale.

According to the findings of the study, communication skills and professional motivation levels show significant relations with the scores of the attitude towards teaching profession value subscale. The two variables in question together account for only $7 \%$ of the variance in the attitude towards teaching profession value subscale.

According to the standardized regression coefficient (ß), the relative order of importance of predictor variables on the attitude towards the profession harmony subscale is professional motivation and communication skills. Upon examining the t-test results on the significance of the regression coefficients, it is seen that only professional motivation is a significant predictor on the attitude towards teaching profession value subscale. 
According to the research findings, as a result of the analyses performed in order to determine the extent to which the level of communication skills and professional motivation of pedagogical formation students predicts their attitudes towards the teaching profession, it was determined that the communication skills and motivation levels of pedagogical formation students predict $21 \%$ of their attitudes towards the teaching profession. The relative order of importance of predictor variables on the attitude towards the profession is professional motivation and communication skills.

It is expected that a high professional motivation level will bring about both academic success during education and professional success after starting to work. Professional motivation can be considered as an important factor in directing and maintaining teacher behaviours.

According to the findings of the study, the attitudes of pre-service teachers towards the profession do not exhibit significant differences by gender, the status of having a stable income, level of education, age, marital status, regular works and grade of education. Similarly Yaşar Ekici (2015) concluded that the attitudes of pre-service teachers towards teaching profession do not differ by age. Accordingly, it can be said that there is a common perception about teaching in all age groups, and age is not a determinant of professional motivation. Also in parallel with Polat (2013), the attitudes of pedagogical formation students on teaching profession do not differ significantly by whether students have a job and the faculty that the students graduated from.

It was determined that there is no significant difference by gender in the attitudes of pedagogical formation students towards teaching profession. In the light of this finding, it can be said that the gender variable does not have an effect on the attitudes of pre-service teachers towards teaching profession. The findings showed that the attitudes towards teaching profession do not vary by gender. The findings of Çapa and Çil, 2000; Erdem and Anılan, 2000; Gürbüztürk and Genç, 2004; Çakır, Kan and Sünbül, 2006; Gömleksiz, Oral and Bulut, 2006; Semerci and Semerci, 2004; Tanel, Şengören and Tanel, 2007; Haciömeroğlu, Başbay, Ünver and Bümen, 2009; Bulut, 2009; Şahin Taşkın, 2010; Özder, Konedralı and Zeki, 2010; Demirtaş, Cömert and Özer, 2011; Tekerek and Polat, 2011; Polat, 2013; Yaşar Ekici, 2015 are in parallel with the present study.

There are different studies which came up with contrasting results. For instance there exist some studies showing that the attitudes of women towards teaching profession are more positive than those of men (Karahan 2003; Çakır, Erkuş and Kılıç, 2004; Oral, 2004; Çakır, 2005; Kaya and Büyükkasap, 2005; Akpınar, Yıldız and Ergin, 2006; Şen 2006; Tay and Tay, 2006; Üredi and Üredi, 2007; Gürbüz and Kışoğlu, 2007; Bozdoğan, Aydın and Yıldırım, 2007; Çapri and Çelikkaleli, 2008; Çiçek-Sağlam, 2008; Üstüner, Demirtaş and Cömert, 2009; Doğan and Çoban, 2009; Pehlivan Baykara, 2008; Pehlivan Baykara, 2010). According to these findings obtained from the studies, it can be said that the attitude towards teaching profession cannot be explained only by gender and personal characteristics may have more effects on it.

According to the research findings, the attitudes of pre-service teachers towards the profession show significant differences by the type of university they graduated from. The attitudes of those graduated from state universities towards teaching profession are higher than of those who are graduated from private (foundation) universities. The studies that are generally carried out in state universities (Çiçek Sağlam, 2008; Baykara Pehlivan, 2008; Bedel, 2008; Çapri and Çelik Kaleli, 2008; Oğuz and Topkaya, 2008; Temizkan, 2008; Bulut, 2009; Çetinkaya, 2009; Üstüner, Demirtaş and Cömert, 2009; Can, 2010; Coşkun, 2011; Tekerek and Polat, 2011; Hussain et al. 2011; Açışlı and Kolomuç, 2012; Bektaş and Nalçacı, 2012; Karadăg, 2012; Kızıltaş, Halmatov and Sarıçam, 2012; Çağlar, 2013) show that pre-service teachers have a positive attitude towards teaching profession. The results of these studies are in parallel with our findings too. Accordingly, it can be said that students prefer state universities more consciously and willingly, and thus, they develop positive attitudes. However the studies of Bulut (2009) and Yaşar Ekici (2015) show that the attitudes of pre-service teachers towards teaching profession do not vary significantly by the type of the university graduated from.

According to the findings of the study, the attitudes of pedagogical formation students towards teaching show significant differences by the bachelor's degree programs they graduated from. It was determined that the attitudes of the graduates of business management/economy towards teaching profession are higher than those graduated from the departments of religious sciences, health care, engineering and social sciences. Significant differences were observed only between the pre-service teachers graduated from business management/economy and religious sciences and social sciences among the groups.

Upon examining the research on the relations between the bachelor's programs that pre-service teachers graduated from and their attitudes towards the profession, different results are encountered. In certain studies, it was seen that the attitudes of pre-service teachers towards teaching profession vary between bachelor's programs. In the studies of Bozdoğan, Aydın and Yıldırım, (2007); Özbek, Kahyaoğlu and Özgen (2007); Üstüner et al. (2009), Bulut (2009), Aksoy (2010), Can (2010), Taşkın Şahin and Hacıömeroğlu (2010), Eraslan and Çakıcı (2011), Kartal and Afacan 
(2012), Kartal et al. (2012), Polat (2013), and Yaşar Ekici (2015), findings that are in parallel with the findings of this study were found, and it was determined that the attitude towards teaching varies by the variable of bachelor's program.

However, in the studies of Demirtaş et al. (2011); Ocak and Demirdelen (2008); Çapri and Çelikkaleli (2008); Şimşek (2005); Erdem et al. (2005); Eraslan and Çakıcı (2011), Demirtaş, Cömert and Özer, 2011), it was determined that the attitude towards teaching does not vary by the variable of bachelor's program. This difference between the findings may be related to the status of whether pre-service teachers prefer the bachelor's program they study consciously and willingly, and the education quality of the bachelor's program they are in.

In the study, it was determined that the attitudes of pre-service teachers towards teaching profession vary by the reason of preferring teaching profession. Accordingly, the attitudes of those who consider teaching as a sacred profession towards teaching profession are higher than of those who have chosen this profession as a result of the desire to become a teacher, employment guarantee and the wish of the family. Among the groups, it was observed that the scale scores of those who consider teaching as a sacred profession are significantly higher than of those who consider teaching as an employment guarantee. The studies of Saban (2003); Pehlivan (2004); Oral (2004); Aslan and Köksal-Akyol (2006); Yumuşak et al. (2006); Gürbüz and Kışoğlu (2007); Bozdoğan, Aydın and Yıldırım (2007); Özder, Konedralı and Zeki (2010); Polat (2013); and Yaşar Ekici (2015) are in parallel with our findings.

This finding obtained from the study can be explained as pedagogical formation students like teaching profession, value teaching profession and will be successful in the teaching profession. Küçükler (1996) states that teachers should love teaching and choose it willingly, in addition to being equipped with sufficient knowledge, skills, and behaviours in their fields. That an individual makes choices that primarily fit his/her own interests, wishes and expectations in regard to the career choice will affect his/her attitude towards teaching profession positively in addition to communication skills and professional motivation.

\section{References}

Acar, V. (2009). Öğretmen Adaylarının İletişim Becerileri, Yayınlanmamış Yüksek Lisans Tezi, Mehmet Akif Ersoy Üniversitesi, Burdur.

Acat, M. B., \& Yenilmez, K. (2004). Eğitim Fakültesi Öğrencilerinin Öğretmenlik Mesleğine Ilişkin Motivasyon (Güdülenme) Düzeyleri. Manas Üniversitesi Sosyal Bilimler Dergisi, 53(12).

Açışlı, S., \& Kolomuç, A. (2012). Sınıf öğretmeni adaylarının öğretmenlik mesleğine yönelik tutumlarının incelenmesi. Eğitim ve Öğretim Araştırmaları Dergisi, 1(2), 266-271.

Akkaya, N. (2009). Öğretmen Adaylarının Öğretmenlik Mesleğine Yönelik Tutumlarının Bazı Değişkenlere Göre İncelenmesi, Dokuz Eylül Üniversitesi Buca Eğitim Fakültesi Dergisi, 35-42.

Akkuzu, N., \& Akkaya, N. (2014). Development and Validity-Reliability Study of Communication Skills Scale for Student Teachers: Suggestion of an Alternative Model, Turkish Studies-International Periodical for the Languages, Literature and History of Turkish or Turkic, 9(8), 111-132.

Altınkurt, Y., Yılmaz, K., \& Erol, E. (2014). Pedagojik Formasyon Programı Öğrencilerinin Öğretmenlik Mesleğine Yönelik Motivasyonları. Trakya Üniversitesi Ĕ̈itim Fakültesi Dergisi, 4(1).

Argon T., \& Zafer, D. (2009). İlköğretim Okulu Yöneticilerinin İletişim Sürecinde Yaşadıkları Problemler (Nitel Bir Çalışma), The Journal of SAU Education Faculty, 18, 99-123.

Arikil, G., \& Yorgancı, B. (2012). Öğretmenlerin, Öğretmen Adaylarının ve Öğrencilerin Motivasyonu Algılama Farklılıkları. X. Ulusal Fen Bilimleri ve Matematik Eğitimi Kongresi

Aşkar, P., \& Erden, M. (1987). Öğretmen Adaylarının Mesleğe Yönelik Tutumları. Çağdaş Eğitim Dergisi, (121), 8-11.

Aslan, D., \& Köksal-Akyol, A. (2006). Okul Öncesi Öğretmen Adaylarının Öğretmenlik Mesleğine Yönelik Tutumları ve Mesleki Benlik Saygılarının İncelenmesi, Çukurova Üniversitesi Sosyal Bilimler Enstitüsü Dergisi, 15(2), 51-60.

Aspy, D., \& Roebuck, R. (1977). Kids Don't Learn From People They Don't Like. Amherst, MA:Human Resource Resources Development Pres.

Aydın, R., \& Sağlam, G. (2012). Öğretmen Adaylarının Öğretmenlik Mesleğine Yönelik Tutumlarının Belirlenmesi. Türk Eğitim Bilimleri Dergisi, 10(2), 257-294.

Azian, A., Raof, A., Ismail, F., \& Hamzah, M. (2013). Communication Strategies of Nonnative Speaker Novice Science Teachers in Second Language Science Classrooms, 41, 283-297.

Bağçeci, B., İbrahim, Y., Kevser, K., \& Derya, K. (2015). Pedagojik Formasyon ve Eğitim Fakültesi Öğrencilerinin 
Öğretmenlik Mesleğine Yönelik Tutumlarının Karşılaştırılması, Erzincan Üniversitesi Eğitim Fakültesi Dergisi, 17(1), 307-324. http://dx.doi.org/10.17556/jef.52416

Baker, J. A. (2006). Contributions of teacher-child relationships to positive school adjustment during elementary school. Journal of School Psychology, 44(2006), 211-229. http://dx.doi.org/10.1016/j.jsp.2006.02.002

Balcı, S. (1996). Danışma Becerileri Eğitiminin Üniversite Öğrencilerinin İletişim Beceri Düzeyine Etkisi. (Unpublished doctoral dissertation). Ondokuz Mayıs Üniversitesi. Samsun, Turkey

Başaran, M., \& Buket, D. O. (2013). Öğretmen Adaylarının Mesleğe İlişkin Motivasyonlarını Etkileyen Faktörler, İönü Üniversitesi Eğitim Fakültesi Dergisi Aralık 2013, 14(3), 129-151.

Başaran, M., \& Erdem, I. (2009). Öğretmen Adaylarının Güzel Konuşma Becerisi İle İlgili Görüşleri Üzerine Bir Araştırma, Kastamonu Eğitim Dergisi, 17(3), 743-754.

Başbay, M., Ünver, G., \& Bümen, N. T. (2009). Ortaöğretim Alan Öğretmenliği Tezsiz Yüksek Lisans Öğrencilerinin Ögretmenlik Mesleğine Yönelik Tutumları: Boylamsal Bir Çalışma, Kuram ve Uygulamada Eğitim Yönetimi, 59, 345-366.

Bedel, E. F. (2008). Okul öncesi öğretmen adaylarının öğretmenlik mesleğine ilişkin tutumları ve bazı kişilik özellikleri arasındaki ilişkiler. Eğitimde Kuram ve Uygulama Dergisi, 4(1), 31-48.

Bieg, S., Backes, S., \& Mittag, W. (2011) The Role of İntrinsic Motivation for Teaching, Teachers' Care And Autonomy Support in Students' Self-Determined Motivation. Journal for Educational Research Online, 3(1), 122-140.

Bloom, B. S. (1998). İnsan Nitelikleri ve Okulda Öğrenme. (Çev: D. A. Özçelik). Ankara: Milli Eğitim Basımevi.

Bolat, S. (1990). Yüksek Öğretimde Ö̆rretim Elemanı-Öğrenci Illetişimi. (Unpublished master's thesis). University of Hacettepe, Ankara, Turkey

Bozdoğan, A. E., Aydın, D., \& Yıldırım, K. (2007). Öğretmen Adaylarının Öğretmenlik Mesleğine İlişkin Tutumları, Ahi Evran Üniversitesi, Kırşsehir Ĕ̈itim Fakültesi Dergisi (KEFAD), 8(2), 83-97.

Brophy, J., \& Evenston, C. (1976). Learning From teaching A developmental perspective. Boston:Allyn,Bacon.

Budak, S. (2005) Psikoloji sözlüğ̈̈. Ankara: Bilim ve Sanat Yayınları.

Bulut, İ. (2009). Öğretmen Adaylarının Öğretmenlik Mesleğine İlişkin Tutumlarının Değerlendirilmesi (Dicle ve Fırat Üniversitesi Örneği), Dicle Üniversitesi Ziya Gökalp Eğitim Fakültesi Dergisi, 14, 13-24.

Buyse, E., Verschueren, K., Verachtert, P., \& Van Damme, J. (2009). Predicting School Adjustment in Early Elementary School: Impact of Teacher-Child Relationship Quality and Relational Classroom Climate. Elementary School Journal, 110(2), 119-141. http://dx.doi.org/10.1086/605768

Büyükses, L. (2010). Öğretmenin İş Ortamindaki Motivasyonunu Etkileyen Etmenler, (Unpublished master's thesis). University of Süleyman Demirel, Isparta, Turkey

Çağlar, Ç. (2013). The relationship between the levels of alienation of the Education Faculty students and their attitudes towards the teaching profession. Educational Sciences: Theory \& Practice, 13(3), 1507-1513.

Çakır, Ö., Kan, A., \& Sünbül, Ö. (2006). Öğretmenlik Meslek Bilgisi ve Tezsiz Yüksek Lisans Programlarının Tutum ve Özyeterlik Açısından Değerlendirilmesi. Mersin Üniversitesi Eğitim Fakültesi Dergisi, 2(1), 36-47.

Can, Ş. (2010). Tezsiz Yüksek Lisans Öğrencilerinin Öğretmenlik Mesleğine Yönelik Tutumları. Muğla Üniversitesi Sosyal Bilimler Enstitüsü Dergisi (ILLKE), 24, 1-28.

Çapa, Y., \& Çil, N. (2000). Öğretmen Adaylarının Öğretmenlik Mesleğine Yönelik Tutumlarının Farklı Değişkenler Açısından İncelenmesi, Hacettepe Üniversitesi Eğitim Fakültesi Dergisi, 18, 69-73.

Çapri, B., \& Çelikkaleli, Ö. (2008). Öğretmen Adaylarının Öğretmenliğe İlişkin Tutum ve Mesleki Yeterlik İnançlarının Cinsiyet, Program Ve Fakültelerine Göre İncelenmesi. İnönü Üniversitesi Eğitim Fakültesi Dergisi, 9(15), 33-53.

Çetin, Ş. (2006). Öğretmenlik Mesleği Tutum Ölçeğinin Geliştirilmesi (Geçerlik ve Güvenirlik Çalışması), Gazi Üniversitesi Endüstriyel Sanatlar Ĕ̈itim Fakültesi Dergisi, 18, 28-37.

Çetinkanat, C. (1997). Öğretmenlerin İletişim Becerileri, Paper presented at the 3th International Elementary Teaching Semposium, Adana-Turkey: Çukurova University.

Çetinkaya, Z. (2009). Türkçe öğretmen adaylarının öğretmenlik mesleğine ilişkin tutumlarının belirlenmesi. İlköğretim Online, 8(2), 298-305.

Ceyhan, A. A. (2006). An Investigation of Adjustement Levels of Turkish University Students with Respect to 
Perceived Communication Skill Levels. Social Behaviour and Personality, 34(4), 367-379. http://dx.doi.org/10.2224/sbp.2006.34.4.367

Chant, S., Jenkinson, T., Randle, J., \& Russell, G. (2002). Communication Skills: Some Problems in Nursing Education and Practice. Journal of Clinical Nursing, 11(1), 12-21. http://dx.doi.org/10.1046/j.1365-2702.2002.00553.x

Çiçek-Sağlam, A. (2008). Müzik öğretmenliği bölümü öğrencilerinin öğretmenlik mesleğine yönelik tutumları. Yüzüncü Yll Üniversitesi Ĕ̈itim Fakültesi Dergisi, 5(1), 59-69.

Colangelo, N. G. (1997). Handbook of gifted education. Allyn and Bacon, MA.

Coşkun, M. K. (2011). Din kültürü öğretmen adaylarının öğretmenlik mesleğine yönelik tutumları: İlahiyat-Eğitim DKAB karşılaştırması. EKEV Akademi Dergisi, 15(48), 269-279.

Çuhadar, C., Özgür, H., Akgün, F., \& Gündüz, Ş. (2014). Öğretmen Adaylarının İletişim Becerileri ve İletişimci Biçimleri. Ahi Evran Üniversitesi Kırşehir Eğitim Fakültesi Dergisi, 15(1).

Çulha, M., \& Dereli, A.A. (1987). Atılganlık Eğitimi Programı. Psikoloji Dergisi, 6(21), 124-127.

Czubaj, C. A. (1996). Maintaining Teacher Motivation, Education, V116.

Davies, L., \& Igbal, Z. (1997). Tensions in Teacher Training For School Effectiveness The of Pakistan. School Effectiveness and School improvement, 8(2), 254-266. http://dx.doi.org/10.1080/0924345970080205

De Jesus, S. N., \& Conboy, J. (2001). A stress management course to prevent teacher distressThe International Journal of Educational Management, 15(3), 131-137. http://dx.doi.org/10.1108/09513540110384484

Deci, E. L., \& Ryan, R. M. (1985). Intrinsic Motivation and Self-Determination in Human Behavior. New York: Plenum. http://dx.doi.org/10.1007/978-1-4899-2271-7

Demir, M. K. (2004). Sınıf Öğretmeni Adaylarının Matematik Tutumlarının İncelenmesi, Eğitim Araştırmaları, 14, $162-170$.

Demirci, O. (2011). Illköğretim Okullarında Çalışan Sözleşmeli ve Kadrolu Öğretmenlerin Özlük Haklarındaki Farklilıklar ve İş Motivasyonu. (Unpublished master's thesis). University of Uşak, Turkey.

Demirel, Ö. (1999). Planlamadan Değerlendirmeye Öğretme Sanatı, Ankara: Pegem A Yayıncılık.

Demirtaş, H., Cömert, M., \& Özer, N. (2011). Öğretmen Adaylarının Özyeterlik İnançları ve Öğretmenlik Mesleğine İlişkin Tutumları. Eğitim ve Bilim, 36(159), 98-111.

Deryakulu, D. (2008). Bilişsim Teknolojileri Öğretiminde Sosyo-Psikolojik Değişkenler, Akademi Yayınları. Ankara.

Dilekman, M., Başçı, Z., \& Bektaş, F. (2008). Eğitim Fakültesi Öğrencilerinin İletişim Becerileri. Atatürk Üniversitesi Sosyal Bilimler Enstitüsü Dergisi, 12(2).

Doğan, T., \& Çoban, A. E. (2009). Eğitim Fakültesi Öğrencilerinin Öğretmenlik Mesleğine Yönelik Tutumları ile Kayg1 Düzeyleri Arasındaki İlişkinin İncelenmesi. Eğitim ve Bilim, 34(153), 157-168.

Dökmen, Ü. (1997). İletişim Çatışmaları ve Empati. Sistem Yayıncılık. İstanbul.

Durmuşoğlu, M. C., Yanık, C., \& Akkoyunlu, B. (2009). Türk ve Azeri Öğretmen Adaylarının Öğretmenlik Mesleğine Yönelik Tutumları. Hacettepe Üniversitesi Eğitim Fakültesi Dergisi, 36, 76-86.

Durukan, E., \& Maden, S. (2010). Türkçe Öğretmenlerinin İletişim Becerileri Üzerine Bir Araştırma, Gaziosmanpaşa Üniversitesi Sosyal Bilimler Araştırmaları Dergisi, ISSN: 1306-732X, 5(1), 59-74.

Ekici, Y. F. (2015). Öğretmen Adaylarının Öğretmenlik Mesleğine Yönelik Tutumlarının Çeşitli Değişkenler Açısından İncelenmesi (İstanbul Sabahattin Zaim Üniversitesi Örneği), Uluslararası Sosyal Araştırmalar Dergisi, Cilt: 7 Sayı: 35 Volume: 7 Issue: 35, S.658-665.

Eraslan, L., \& Çakıcı, D. (2011). Pedagojik Formasyon Programı Öğrencilerinin Öğretmenlik Mesleğine Yönelik Tutumları, Kastamonu Eğitim Dergisi, 19(2), 427-438.

Erdem, A. R., \& Anılan, H. (2000). PAÜ Eğitim Fakültesi Sınıf Öğretmenliği Öğrencilerinin Öğretmenlik Mesleğine İlişkin Tutumları. Pamukkale Üniversitesi Eğitim Fakültesi Dergisi (IV Ulusal Sınıf Öğretmenliği Sempozyumu Bildirileri Özel Sayıs1), 7, 144-149.

Gömleksiz, M. N., Oral, B., \& Bulut, İ. (2006). Ortaöğretime Nitelikli Öğretmen Yetiştirmede Tezsiz Yüksek Lisans Uygulaması. Orta Öğretimde Yeniden Yapılanma Sempozyumu 20-22 Aralık 2004 Bildiriler Kitabı içinde 545- 551, Ankara: MEB Talim Terbiye Kurulu Başkanlığı.

Güçlü, N. (2001). İletişim. Ankara: Nobel Yayıncılık. 
Gürbüz, H., \& Kışoğlu, M. (2007). Tezsiz Yüksek Lisans Programına Devam Eden Fen-Edebiyat ve Eğitim Fakültesi Öğrencilerinin Öğretmenlik Mesleğine Yönelik Tutumları (Atatürk Üniversitesi Örneği), Erzincan Eğitim Fakültesi Dergisi, 9(2), 71-83.

Gürbüztürk, O., \& Genç, S. Z. (2004). Öğretmen Adaylarının Öğretmenlik Mesleğine İlişkin Görüşleri. İnönü Üniversitesi Ĕ̈itim Fakültesi Dergisi, 5(7), 47-62.

Hacıömeroğlu, G., \& Şahin Taşkın, Ç. (2010). Fen Bilgisi Öğretmenliği ve Ortaöğretim Fen ve Matematik Alanları (OFMA) Eğitimi Bölümü Öğretmen Adaylarının Öğretmenlik Mesleğine İlişkin Tutumları. Ahi Evran Üniversitesi Ĕ̈itim Fakültesi Dergisi, 11(1), 77-90.

Hazneci Y. (2012) Oluşturmacı Öğretmen İletişim Beceri Ölçeğinin Geliştirilmesi ve İlköğretim Öğretmenlerinin Sınıf İçi İletişim Becerilerinin İncelenmesi (Unpublished doctoral dissertation). University of Marmara, İstanbul, Turkey.

İnceoğlu, M. (2010). Tutum Algl İletişim (5. Baskı). İstanbul: Beykent Üniversitesi Yayınevi.

Karadağ, E., Baloğlu, N., \& Küçük, E. (2010). Yönetici Denetimi Algısının Öğretmenlerin Mesleki Motivasyon Düzeyine Etkisi: Bir Path Analizi Çalışması. Türk Ĕ̆itim Bilimleri Dergisi, 8(2), 417-437.

Karagöz, Y., \& Kösterelioğlu, İ. (2008). İletişim Becerileri Değerlendirme Ölçeğinin Faktör Analizi Metodu İle Geliştirilmesi. Dumlupınar Üniversitesi Sosyal Bilimler Dergisi, 21, 81-98.

Karasar, N. (2005). Bilimsel araştırma yöntemi. Ankara: Nobel Yayın Dağıtım.

Kartal, T., \& Afacan, Ö. (2012). Pedagojik Formasyon Eğitimi Alan Öğretmen Adaylarının Öğretmenlik Mesleğine İlişkin Tutumlarını İncelenmesi. Mehmet Akif Ersoy Üniversitesi Ĕ̈itim Fakültesi Dergisi, 12(24), 76 -96.

Kartal, T., Kaya, V. H., Öztürk, N., \& Ekici, G. (2012). The Exploration of the Attitudes of the Science Teacher Candidates Towards Teaching Profession. Procedia-Social and Behavioral Sciences, 46, 2759-2764. http://dx.doi.org/10.1016/j.sbspro.2012.05.561

Kızıltaş, E., Halmatov, M., \& Sarıçam, H. (2012). Okul öncesi öğretmenliği öğrencilerinin öğretmenlik mesleğine yönelik tutumları (Ağrı İbrahim Çeçen Üniversitesi Örneği). Mehmet Akif Ersoy Üniversitesi Eğitim Fakültesi Dergisi, 12(23), 173-189.

Koepke, M. F., \& Harkins, D. A. (2008). Conflict in the Classroom: Gender Differences in the Teacher-Child Relationship. Early Education \& Development, 19(6), 843-864. http://dx.doi.org/10.1080/10409280802516108

Korkut, F. (2005). Yetişkinlere yönelik iletişim becerileri eğitimi. Hacettepe Üniversitesi Eğitim Fakültesi Dergisi, 28 , 143-149.

Külahoğlu, Ş. (2000). İyi öğretmenlik: Yetenek mi, beceri mi? Eğitim Araştırmaları Dergisi, 2, 52-58 Middlebrook, N.P. (1974). Social Psychology and Modern Life. New York: Alfred A. Knoff.

Ocak, G. (2005). Meslek olarak öğretmenlik. K. Keskinkılıç (Ed.). Öğretmenlik Mesleğine Giriş içinde (s. 37-85). Ankara: Pegem A Yayınları.

Oğuz, A., \& Topkaya, N. (2008). Ortaöğretim alan öğretmenliği öğrencilerinin öğretmen özyeterlik inançları ile öğretmenliğe ilişkin tutumları. Akademik Bakış, 14, 23-36.

Ömür, Y. E., \& Nartgün, Ş. S. (2013). Öğretmen Adaylarının Öğretmenlik Mesleğine İlişkin Tutumları İle Güdülenme Düzeyleri Arasındaki İlişki. Eğitimde Politika Analizi, 2(2), 41-55.

Oral, B. (2004). Eğitim Fakültesi Öğrencilerinin Öğretmenlik Mesleğine İlişsin Tutumları. Eğitim Araştırmaları, 15, 88-98.

Özder, H., Kodralı, G., \& Zeki, C. P. (2010). Öğretmen Adaylarının Öğretmenlik Mesleğine Yönelik Tutumlarının Çeşitli Değişkenler Açısından İncelenmesi. Kuram ve Uygulamada Eğitim Yönetimi, 16(2), 253-275.

Özer, A. K. (1995). Iletişimsizlik Becerisi. İstanbul: Varlık Yayınları, 406.

Pehlivan, B. K. (2008). Sınıf Öğretmeni Adaylarının Sosyo-Kültürel Özellikleri ve Öğretmenlik Mesleğine Yönelik Tutumları Üzerine Bir Çalışma. Mersin Üniversitesi Eğitim Fakültesi Dergisi, 4(2), 151-168.

Pehlivan, B. K. (2010). Öğretmen Adaylarının Öğrenme Stilleri ve Öğretmenlik Mesleğine Yönelik Tutumları Üzerine Bir Çalışma. Illköğretim Online, 9(2), 749-763.

Pehlivan, K. B. (2004). Sınıf Öğretmeni Adaylarının Öğretmenlik Mesleğine Yönelik Tutumları ve Okul Tutumları Arasındaki İliş̧ki. Eğitim Araştırmaları, 14, 211-218.

Pehlivan, K. B. (2005). Öğretmen Adaylarının İletişim Becerisi Algıları Üzerine Bir Çalışma, İlköğretim Online, 4(2), 
$17-23$.

Pektaş, S. (1989). Sözel Olmayan Öğretmen Davranışlarının Öğretime Etkileri. Çağdaş Eğitim, 14(148), 32-36.

Pianta, R. C., Steinberg M. S., \& Rollins K. B. (1995). The First Two Years Of School: Teacher-Child Relationships and Deflections in Children's Classroom Adjustment. Development and Psychopathology, 7, 295-312. http://dx.doi.org/10.1017/S0954579400006519

Pithers, R. T., \& Fogarty, G. J. (1995). Occupational stress among vocational teachers'.16. British Journal of Educational Psychology, 65, 3-14. http://dx.doi.org/10.1111/j.2044-8279.1995.tb01127.x

Polat, S. (2013). Pedagojik Formasyon Sertifika Programı ve Eğitim Fakültesi Öğrencilerinin Öğretmenlik Mesleğine Yönelik Tutumlarının İncelenmesi, e-international journal of educational research, 4(2), 48-60.

Roness, D. (2011). Still motivated? The motivation for teaching during the second year in the profession. Teaching and Teacher Education, 27, 628-638. http://dx.doi.org/10.1016/j.tate.2010.10.016

Rudasill, K. M. (2011). Child Temperament, Teacher-Child İnteractions, and Teacher-Child Relationships: A Longitudinal İnvestigation from First to Third Grade. Early Childhood Research Quarterly, 26(2), 147-156. http://dx.doi.org/10.1016/j.ecresq.2010.07.002

Saban, A. (2003). Sınıf Öğretmeni Adaylarının Demografik Özellikleri ve Mesleki Eğilimleri. Eğitim Araştırmaları, 3(10), 91-101.

Şahin, F. Y. (1998). Grupla İletişim Becerileri Eğitiminin Üniversite Öğrencilerinin İletişim Beceri Düzeylerine Etkisi. Eğitim ve Bilim, 22(110), 12-19.

Selçuk, Z. (1994). Eğitim Psikolojisi. Ankara: Atlas Kitabevi.

Semerci, N., \& Semerci, Ç. (2004). Türkiye'de Öğretmenlik Tutumları. Fırat Üniversitesi Sosyal Bilimler Dergisi, 14(1), 137-146.

Şişman, M. (2006). Eğitim bilimine giriş. Ankara: Pegem A Yayıncılık

Tanel, R., Şengören, S. K., \& Tanel, Z. (2007). Fizik Öğretmen Adaylarının Öğretmenlik Mesleğine İlişkin Tutumlarının Farklı Değiş̧enler Açısından İncelenmesi, Pamukkale Üniversitesi Eğitim Fakültesi Dergisi, 2(22), 1-9.

Tanrıverdi, S. (2007). Katılımcı Okul Kültürünün Yabancı Dil Öğretmenlerinin İs Motivasyonuyla İlişsisine Yönelik Örnek Bir Çallş̧ma (Unpublished master's thesis). University of Yeditepe, İstanbul, Turkey.

Tarhan, U. (2000). Effect of Interpersonel Skills Training on Teachers Communication Skills and Self Awareness, PhD dissertation, The Middle East Technical University, Ankara.

Taş, S. (2005). Sinı Öğretmenlerinin Motivasyonunu Etkileyen Faktörler (Unpublished master's thesis). University of Selçuk, Konya Turkey.

Taşkın, Ş. Ç., \& Hacıömeroğlu, G. (2010). İlköğretim Bölümü Öğretmen Adaylarının Mesleğe Yönelik Tutumları: Nicel Ve Nitel Verilere Dayalı Bir İnceleme. İlköğretim Online (Elementary Education Online), 9(2), 922-933.

Tekerek, M., \& Polat, S. (2011). Öğretmen Adaylarının Öğretmenlik Mesleğine İlişkin Tutumları, 5th International Computer \& Instructional Technologies Symposium, 22-24.

Temizkan, M. (2008). Türkçe öğretmeni adaylarının öğretmenlik mesleğine yönelik tutumları üzerine bir araştırma. Türk Eğitim Bilimleri Dergisi, 6(3), 461-486.

Terzi, A. R., \& Tezci, E. (2007) Necatibey Eğitim Fakültesi Öğrencilerinin Öğretmenlik Mesleğine İlişkin Tutumları. Kuram ve Uygulamada Eğitim Yönetimi, 52, 593-614.

Terzi, M., Ünal, M., \& Gürbüz, M. (2012). İlköğretim matematik öğretmen adaylarının matematiğe yönelik akademik güdülenme düzeylerinin bazı değişkenler açısından incelenmesi. Pegem Ĕgitim ve Öğretim Dergisi, 2(1), 51-60.

Tsigilis, N., \& Gregoriadis, A. (2008). Measuring Teacher-Child Relationships in the Greek Kindergarten Setting: A Validity Study of the Student-Teacher Relationship Scaleshort form. Early Education \& Development, 19(5), 816835. http://dx.doi.org/10.1080/10409280801975826

Tümkaya, S. (2011). Sınıf Öğretmenliği Öğrencilerinin İletişim Becerileri ile Öğretmenlik Tutumlarının İncelenmesi, Ç.Ü. Sosyal Bilimler Enstitüsü Dergisi, 20(2), 49-62.

Uslu, M. (2013). Pedagojik Formasyon Öğrencilerinin Kişilik Özellikleri ve Öğretmenlik Mesleğine Yönelik Tutumları Arasındaki İlişkinin İncelenmesi. International Journal of Human Sciences, 10(2), 233-245.

Üstün, E., Erkan, S., \& Akman, B. (2004). Türkiye'de Okul Öncesi Öğretmenliği Öğrencilerinin Öğretmenlik 
Mesleğine Yönelik Tutumlarının İncelenmesi. Kırgızistan-Türkiye Manas Üniversitesi Sosyal Bilimler Dergisi, 10 , 129-136.

Üstüner, M. (2006). Öğretmenlik Mesleğine Yönelik Tutum Ölçeğinin Geçerlik ve Güvenirlik Çalışması, Kuram ve Uygulamada Eğitim Yönetimi, 45, 109-127.

Üstüner, M., Demirtaş, H., \& Cömert, M. (2009). Öğretmen Adaylarının Öğretmenlik Mesleğine Yönelik Tutumları (İnönü Üniversitesi, Eğitim Fakültesi Örneği). Ĕgitim ve Bilim, 34(151), 140-155.

Vondra, J. I., Shaw, D. S., Swearingen, L., Cohen, M., \& Owens, E. B. (1999). Early relationship quality from home to school: A longitudinal study. Early Education \& Development, 10(2), 163-190. http://dx.doi.org/10.1207/s15566935eed1002_4

Weis, L., Combleth, C., Zeeichner, K. M., \& Appie, M. W. (1990). Curriculum for tomorrow's schools. Buffalo Research institute an Education for Teaching Graduate School of Education, State University of New York: May, $1-28$.

Yazıcı, H. (2009). Öğretmenlik Mesleği, Motivasyon Kaynakları ve Temel Tutumlar: Kuramsal Bir Bakış, Kastamonu Eğitim Dergisi, 17(1), 33-46.

Y1lmaz, F. (2009). Eğitim Örgütlerinde Örgüt Kültürünün Öğretmenlerin İş Motivasyonu Üzerindeki Etkisi (Unpublished master's thesis). University of Selçuk, Konya Turkey.

Yüksel, S. (2004). Tezsiz Yüksek Lisans Programının Öğrencilerin Öğretmenlik Mesleğine İlişkin Tutumlarına Etkisi, Uludağ Üniversitesi Eğitim Fakültesi Dergisi, 17(2).

Yumuşak, A., Aycan, N., Aycan, Ş., Çelik, F., \& Kaynar, H. Ü. (2006). Muğla Üniversitesi Tezsiz Yüksek Lisans Programı İle Eğitim Fakültesi Lisans Programı Öğrencilerinin Öğretmenlik Mesleğine Yönelik Tutum ve Endişelerinin Karşılaştırılması. 15. Ulusal Eğitim Bilimleri Kongresi Bildiri Özetleri, 13-15 Eylül 2006, Muğla, Turkey: University of Muğla.

\section{$(\mathrm{cc}) \mathrm{BY}$}

This work is licensed under a Creative Commons Attribution 3.0 License. 